Creating Productive and Upcoming Sport Education Profesional Hmzanwadi University

Vol.4, No.1, Juni 2021, Hal. 45-49

e-ISSN 2614-8781

\title{
KORELASI LATIHAN MANDIRI SELAMA PANDEMI COVID 19 DENGAN KECEMASAN DAN DEPRESI ATLIT
}

\author{
Arnaz Anggoro Saputro 1 \\ email: $\underline{\text { arnaz_boy@ymail.com }}{ }^{1}$ \\ ${ }^{1}$ STKIP PGRI Jombang
}

\begin{abstract}
Abstrak
Tujuan dari penelitian ini adalah untuk mengetahui korelasi antara latihan mandiri selama pandemi Covid 19 dengan kecemasan dan depresi. Penelitian ini menggunakan metode kuantitatif dengan studi korelasional. Sampel penelitian ini adalah atlit bola basket PORPROV Kabupaten Jombang sebanyak 32 atlit yang diambil dengan menggunakan teknik total sampling. Instrumen dalam penelitian ini adalah angket latihan mandiri selama pandemi Covid 19, angket kecemasan, dan angket depresi dibuat secara mandiri dan di validasi oleh ahli pakar. Dengan hasil penelitian antara latihan mandiri selama pandemi Covid 19 dengan kecemasan adalah nilai Sig. $(0.000)<0.05$, sedangkan nilai sig. antara latihan mandiri selama pandemi Covid 19 dengan depresi adalah nilai sig. $(0.006)<0.05$. Menunjukkan bahwa terdapat hubungan yang signifikan antara variabel latihan mandiri selama pandemi Covid 19 dengan kecemasan dan terdapat hubungan yang signifikan antara variabel latihan mandiri selama pandemi Covid 19 dengan depresi.
\end{abstract}

Kata kunci: Latihan mandiri selama pandemi Covid 19, Kecemasan, Depresi

\section{Abstract}

The purpose of this study was to determine the correlation between self-exercise during the Covid 19 pandemic and anxiety and depression. This research uses quantitative methods with a correlational study. The sample of this research is 32 athletes of basketball PORPROV Jombang Regency who were taken using total sampling technique. The instruments in this study were an independent exercise questionnaire during the Covid 19 pandemic, an anxiety questionnaire, and a depression questionnaire made independently and validated by expert experts. With the results of research between independent training during the Covid 19 pandemic and anxiety, the Sig. (0.000) < 0.05, while the sig. between self-training during the Covid 19 pandemic and depression is of sig value. $(0.006)<0.05$. This shows that there is a significant relationship between the variable self-exercise during the Covid 19 pandemic and anxiety and there is a significant relationship between the variable self-exercise during the Covid 19 pandemic and depression.

Keywords: Self-exercise during the Covid 19 pandemic, Anxiety, Depression

\section{A. Pendahuluan}

Masa pandemi Covid 19 menjadikan semua kegiatan tidak bisa dilakukan dengan optimal, baik aktifitas kerja, aktifitas pendidikan, aktifitas sosial maupun aktifitas olahraga. Ketika pandemi Covid 19 terus berkembang di hampir semua wilayah, berbagai langkah perlindungan telah diperkenalkan oleh pihak berwenang, termasuk penutupan sekolah dan universitas, larangan perjalanan, acara budaya dan olahraga, dan pertemuan sosial (Parnell, 2020). Akibat dari pandemi Covid 19 ini memaksa semua aktivitas dibatasi dan melakukan Work 
From Home (WFH). Salah satunya para atlit Bola Basket PORPROV Kabuapten Jombang yang sedang mempresiapkan PORPROV tahun 2022. Sehingga para atlit melakukan latihan mandiri di rumah masing-masing dengan tetap melaksanakan program latihan yang telah diberikan pelatih. Meskipun tidak ada data epidemiologis yang pasti mengenai efek psikologis Covid 19 pada individu dan pengaruhnya terhadap kesehatan masyarakat saat ini, hasil dari jumlah terbatas studi sangat luar biasa. Misalnya, penelitian telah melaporkan bahwa "sepertiga dari orang yang diwawancarai di China dan Jepang mengalami kecemasan yang parah, dan sekitar setengahnya mengalami kecemasan sedang" (Wang, Pan, Wan, Tan, Xu, Ho, \& Ho. 2020; Shigemura, Ursano, Morganstein, Kurosawa, \& Benedek. 2020). Demikian pula, penelitian telah menemukan bahwa "ketakutan tertular Covid 19 mengarah pada konsekuensi emosional dan perilaku yang intens seperti kebosanan, kesepian, kecemasan, masalah tidur dan amarah" (Brooks, Webster, Smith, Woodland, Wessely, Greenberg, \& Rubin. 2020).

Telah dilaporkan bahwa "depresi, kecemasan gangguan, gangguan stres pasca-trauma (PTSD), gangguan paranoid dan psikotik, dan bahkan bunuh diri mungkin merupakan konsekuensi emosional dan perilaku dari ketakutan yang disebabkan oleh Covid 19" (Wang et al. 2020). Penelitian telah menunjukkan bahwa "jenis reaksi ini, yang dapat dikembangkan berdasarkan keadaan ketakutan, mungkin lebih sering terjadi pada individu yang sebelumnya mengalami psikologis gangguan dan mengalami jam malam karantina atau berkepanjangan" (Brooks et al. 2020). Sebagai akibat dari Situasi Covid 19, individu dapat menunjukkan emosi negatif akibat suatu peristiwa mereka telah menyaksikan dan rasa takut berkembang sebagai hasil dari informasi yang diperoleh. Oleh karena itu seorang pelatih harus mengetahui keadaan atlitnya dalam aspek psikologi. Kerena dengan adanya pandemi Covid 19 ini kebiasaan para atlit menjadi berubah secara tidak langsung. Atlit dalam melaksanakan isolasi saat latihan atau tinggal di rumah untuk waktu yang lama mungkin berdampak negatif pada status kesehatan mental atlit juga. Masa isolasi dapat menyebabkan terjadinya efek psikologis seperti depresi dan kecemasan dengan menyebabkan perubahan kondisi kehidupan masyarakat, penurunan kontak sosial dan fisik, serta perpisahan dengan orang yang mereka cintai (Şenışık, Denerel, Köyağasığlu \& Tunç, 2020).

\section{B. Metode}

Metodologi yang digunakan dalam penelitian ini adalah metodologi deskriptif dengan teknik korelasional. Maksum (2016, hlm. 68) menjelaskan bahwa, "Penelitian deskriptif adalah penelitian yang dilakukan untuk menggambarkan gejala, fenomena atau peristiwa tertentu. Populasi yang diteliti adalah atlit Bola Basket PORPROV Kabuapten Jombang berjumlah 32 atlit. Dalam penelitian ini, peneliti menentukan pengambilan sampel dengan cara total sampling berjumlah 32 atlit. Penelitian ini merupakan penelitian yang korelasional yang akan menyelidiki ada tidaknya korelasi antara variabel bebas dan variabel terikat. Desain penelitian korelasi perlu suatu pola yang sesuai dengan variabel-variabel yang terkandung dalam tujuan penelitian dan hipotesis yang akan digunakan adalah hubungan latihan mandiri selama pandemi Covid 19 dengan Kecemasan dan Depresi atlit Bola tangan Pelatda Jawa Barat. Instrumen atau alat yang digunakan dalam penelitian ini berupa angket google form dibuat secara mandiri dan di validasi oleh ahli pakar. Format instrumen latihan mandiri selama pandemi Covid 19 ini dibuat untuk menggambarkan keadaan aktivitas atlit saat latihan pada pandemi Covid 19 dengan mengacu pada prinsip dan norma latihan. Mengenai Instrumen Kecemasan mengadaptasi dari teori Singgih (dalam Komarudin 2017, hlm. 102-103). Sedangkan Instrumen Depresi mengadaptasi dari teori Beck (dalam Burns, 1998). Tahapan penelitian yang dilakukan adalah sebagai berikut: (1) Menentukan populasi (2) Menentukan sampel (3) Membuat instrumen penelitian (4) Uji coba 
insrtumen (5) Mengumpulkan data (6) Mengolah data (7) Menarik kesimpulan. Hasil data di analisis menggunakan SPSS v21.0 for Windows kemudian disajikan berupa tebel. Tempat penelitian dilakukan secara Work From Home para atlit masing-masing serta dipandu oleh pelatih pengisian angket via aplikasi Zoom.

\section{Hasil dan Pembahasan}

Berdasarkan data yang diperoleh yaitu data dari angket latihan mandiri selama pandemi Covid 19, kecemasan, dan depresi merupakan data mentah sehingga diperlukan pengolahan data untuk dijadikan data yang baku. Untuk dapat memberikan gambaran umum tentang data yang diperoleh dari hasil penelitian maka, data-data tersebut diolah dan dianalisis melalui bantuan program SPSS v21.0 for Windows.

Tabel 1.1. Data Statistika Ke 3 Variabel

\begin{tabular}{|c|c|c|c|c|c|}
\hline & $\mathrm{N}$ & Min & Max & Mean & $\begin{array}{c}\text { Std. } \\
\text { Deviasi }\end{array}$ \\
\hline $\begin{array}{l}\text { Latihan } \\
\text { Mandiri }\end{array}$ & 32 & 62 & 73 & 67.41 & 2.961 \\
\hline Kecemasan & 32 & 50 & 57 & 53.75 & 1.901 \\
\hline Depresi & 32 & 70 & 82 & 74.84 & 3.638 \\
\hline
\end{tabular}

Tabel diatas menunjukkan bahwa data latihan mandiri selama pandemi Covid 19 memiliki jumlah sampel sebanyak 32 dengan nilai minimum sebesar 62 dan nilai maximum sebesar 73. Selain itu data latihan mandiri selama pandemi Covid 19 terdapat mean sebesar 67.41 dan std.deviation sebesar 2.961. Selanjutnya data kecemasan memiliki jumlah sampel sebanyak 32 dengan nilai minimum sebesar 50 dan nilai maximum sebesar 57. Selain itu data latihan terdapat mean sebesar 53.75 dan std.deviation sebesar 1.901. Sedangkan data depresi memiliki jumlah sampel sebanyak 32 dengan nilai minimum sebesar 70 dan nilai maximum sebesar 82 . Selain itu data latihan terdapat mean sebesar 74.84 dan std.deviation sebesar 3.638. Dari hasil temuan yang diperoleh bahwa atlit bola basket PORPROV Kabupaten Jombang menunjukkan adanya gejala-gejala kecemasan dan depresi saat melakukan latihan mandiri. Para atlit mengalami adanya perubahan secara fisik maupun psikisnya. Hal ini dapat menggambarkan kecemasan dan depresi atlit pada saat pertandingan nanti di PORPROV Jawa Timur yang akan digelar pada tahun 2022.

Masa pandemi Covid 19 menjadikan semua kegiatan tidak bisa dilakukan dengan optimal, baik aktifitas kerja, aktifitas pendidikan, aktifitas sosial maupun aktifitas olahraga. Akibat dari pandemi Covid 19 ini memaksa para atlit untuk melakukan latihan mandiri di rumah masing-masing dengan tetap melaksanakan program latihan yang telah diberikan pelatih. Masa isolasi ini berhubungan dengan kurangnya sesi latihan dan persaingan dalam tim mungkin juga telah menyebabkan komunikasi yang menurun antara pemain dan pelatih, dan untuk kondisi latihan individu yang tidak memadai (Daniel, Riaza, Mónica \& Ignacio, 2020). Sebagai akibat dari Situasi Covid 19, individu dapat menunjukkan emosi negatif akibat suatu peristiwa mereka telah menyaksikan dan rasa takut berkembang sebagai hasil dari informasi yang diperoleh. penelitian telah melaporkan bahwa "sepertiga dari orang yang diwawancarai di China dan Jepang mengalami kecemasan yang parah, dan sekitar setengahnya mengalami kecemasan sedang" (Wang, Pan, Wan, Tan, Xu, Ho, \& Ho. 2020; Shigemura, Ursano, Morganstein, Kurosawa, \& Benedek. 2020). Telah dilaporkan bahwa "depresi, kecemasan gangguan, gangguan stres pasca- 
trauma (PTSD), gangguan paranoid dan psikotik, dan bahkan bunuh diri mungkin merupakan konsekuensi emosional dan perilaku dari ketakutan yang disebabkan oleh Covid 19" (Wang et al. 2020). Masa isolasi dapat menyebabkan terjadinya efek psikologis seperti depresi dan kecemasan dengan menyebabkan perubahan kondisi kehidupan masyarakat, penurunan kontak sosial dan fisik, serta perpisahan dengan orang yang mereka cintai (Şenışık, Denerel, Köyağasığlu \& Tunç, 2020). Oleh karena itu seorang pelatih harus mengetahui keadaan atlitnya dalam aspek psikologi. Kerena dengan adanya pandemi Covid 19 ini kebiasaan para atlit menjadi berubah secara tidak langsung. Kecemasan dan depresi yang diukur sekarang ini menggambarkan kecemasan dan depresi atlit pada saat pertandingan nanti di PORPROV Jawa Timur tahun 2022 sekitar 60-70\%. Alasan kecemasan dan depresi diukur sekarang, bahwasannya kecemasan dan depresi bertanding yang masih memiliki waktu sampai pada PORPROV Jawa Timur Tahun 2022 itu efek daripada Covid 19 yang terjadi.

\section{Simpulan}

Penelitian ini menyimpulkan bahwa terdapat korelasi yang signifikan antara latihan mandiri selama pandemi Covid 19 dengan kecemasan pada atlit Bola Basket PORPROV Kabupaten Jombang, dan terdapat hubungan yang signifikan antara latihan mandiri selama pandemi Covid 19 dengan depresi atlit Bola Basket PORPROV Kabupaten Jombang.

\section{Daftar Pustaka}

Brooks, S. K., Webster, R. K., Smith, L. E., Woodland, L., Wessely, S., Greenberg, N., \& Rubin, G. J. (2020). The psychological impact of quarantine and how to reduce it: Rapid review of the evidence. The Lancet.

Daniel Mon Lopez, Alfonso de la Rubia Riaza, Monica Hontoria Galan \& Ignacio Refoyo Roman. (2020). The Impact of Covid 19 and the effect of Psychological Factor on Training Conditions of Handball Players. Environmental Research and Public Health.

Fraenkel, J. R., \& Wallen, N. E. (2012). The Basic of Educational Research. How to design and evaluate research in educatiuon with PowerWeb.

Hudah, M., Widiyatmoko, F. A., Pradipta, G. D., \& Maliki, O. (2020). Analisis Pembelajaran Pendidikan Jasmani Di Masa Pandemi Covid-19 Di Tinjau Dari Penggunaan Media Aplikasi Pembelajaran Dan Usia Guru. Jurnal Porkes, 3 (2), 93-102.

Igor Jukic, Julio Calleja-González, Francesc Cos \& Francesco Cuzzolin. (2020). Strategies and Solutions for Team Sports Athletes in Isolation due to COVID 19. sports.

Komarudin. (2017). Psikologi Olahraga. Bandung: PT. Remaja Rosdakarya.

Maksum. (2016). Metodologi Penelitian dalam Olahraga. Surabaya: Unesa University Press

Parnell, D. (2020). COVID-19, networks and sport. Managing Sport and Leisure, 0 (0), 1-7.

Seçkin Şenışık, Nevzad Denerel, Ogün Köyağasığlu \& Serhat Tunç. (2020). The Effect of Isolation on Athletes' Mental Health during the COVID 19 Pandemic. The Physician and Sportsmedicine.

Shigemura, J., Ursano, R. J., Morganstein, J. C., Kurosawa, M., \& Benedek, D. M. (2020). Public responses to the novel 2019 coronavirus (2019-nCoV) in Japan . Mental health consequences and target populations. Psychiatry and Clinical Neurosciences. 
Saputro, A. A., Saputra, Y. D., \& Prasetyo, G. B. (2020). Analisis Dampak Covid-19 Terhadap Kesadaran Masyarakat Dalam Penerapan Protokol Kesehatan. Jurnal Porkes, 3(2), 81-92.

Wang, C., Pan, R.,Wan, X., Tan, Y., Xu, L., Ho, C. S., \& Ho, R. C. (2020). Immediate psychological responses and associated factors during the initial stage of the 2019 coronavirus disease (COVID-19) epidemic among the general population in China. International Journal of Environmental Research and Public Health. 